\title{
Association of monocytes and neutrophils with early events of blastocyst implantation in mice
}

\author{
M. T. McMaster ${ }^{1 *}$ S. K. Dey ${ }^{2}$ and G. K. Andrews ${ }^{1}{ }^{\dagger}$ \\ ${ }^{1}$ Department of Biochemistry and Molecular Biology, and ${ }^{2}$ Departments of Obstetrics - Gynecology \\ and Physiology, Ralph L. Smith Research Center, University of Kansas Medical Center, Kansas City, \\ KS 66160, USA
}

The distribution and activation of monocytes and neutrophils in the mouse uterus were examined early in the process of blastocyst implantation. Implantation regions, detected by increased capillary permeability at sites of blastocyst apposition to the uterine luminal epithelium, could be distinguished at about $21: 00 \mathrm{~h}$ on day 4 of pregnancy (day $1=$ day of vaginal plug), and were also examined at 01:00, 05:00 and 09:00 h on day 5. Serial sections containing the implanting blastocyst (implantation sites), and random sections of interimplantation regions were examined by immunohistochemistry using interleukin- $1 \beta$ as a marker for monocytes-macrophages and lactoferrin as a marker for neutrophils in the uterine stroma. At implantation sites, interleukin- $1 \beta$-positive cells were transiently abundant within endometrial capillaries. In interimplantation regions only a few interleukin- $1 \beta$-positive cells were dispersed at the myometrial-stromal junction. Northern blot hybridization to RNAs from implantation and interimplantation regions showed that the abundance of interleukin$1 \beta$ and interleukin- $1 \alpha$ mRNAs was much lower than that found in the uterus during acute inflammation. However, these cytokine mRNAs were more abundant in implantation regions. On the evening of day 4 and the early morning of day 5 , lactoferrin-positive neutrophils were detected juxtaposed to the basolateral surface of the antimesometrial epithelial cells surrounding the implanting blastocyst. They were primarily at the myometrial-stromal junction in interimplantation regions. Metallothionein gene expression was examined as a marker for uterine responses to inflammatory reactions. In situ hybridization showed high metallothionein mRNA specifically in antimesometrial epithelial cells underlying the implanting blastocyst and in deeper stromal cells in the implantation region at 05:00 h on day 5 . These data suggest that monocytes and neutrophils are transiently abundant near implantation sites, and neutrophils become closely associated with the luminal epithelium. Although monocytes are not highly active in cytokine gene expression, neutrophils and monocytes may play a role in a localized inflammatory response during the initiation of blastocyst implantation.

\section{Introduction}

The uterine responses to blastocyst implantation have certain similarities to classical inflammatory reactions. Beer and Billingham (1978) suggested that uterine pro-inflammatory responses are the result of maternal immunological reactions to the embryo, considered as an 'allograft'. These responses include localized increased stromal vascular permeability (Psychoyos, 1973), oedema (Potts, 1968) and increased concentrations of prostaglandins (Kennedy, 1977) in the regions of blastocyst implantation. The presence of macrophages (Tachi et al., 1981) and neutrophils in the rodent uterus at implantation

${ }^{*}$ Current address: Department of Stomatology, HSW 604, University of California San Francisco, 3rd and Parnassus, San Francisco, CA 94143, USA.

†Correspondence.

Received 13 January 1993. sites or at regions of oil-induced decidual cell reaction have been documented (Finn and Pope, 1991). However, in these studies, no molecular markers were used to examine the state of activation of these immune cells.

Heightened expression of cytokine genes (interleukin (IL)- $1 \alpha$, IL-1 $\beta$, IL- 6 , tumour necrosis factor $\alpha$ (TNF- $\alpha)$ ) is a hallmark of activated macrophages. Injection of lipopolysaccharide (LPS), IL- $1 \alpha$ or IL- $1 \beta$ causes coordinated rapid, but transient, increases in the relative abundance of each of these cytokine mRNAs in the mouse uterus (De et al., 1990). A large influx of cytokinepositive macrophages with increased cytokine gene expression in the uterus after coitus (McMaster et al., 1992b) also suggests activation of uterine macrophages in response to seminal fluid. These immune cells are distributed throughout the endometrial stroma, but are more concentrated at the luminal subepithelial region on day 1 of pregnancy. In contrast, macrophages are sparse and are detected only in the deep endometrium and Downloaded from Bioscientifica, com at 04/26/2023 10:29:34AM (C) 1993 Journals of Reproduction and Fertility Ltd via free access 
myometrium on day 4 when cytokine mRNA abundance is low (McMaster et al., 1992b). Neutrophils (lactoferrin (LF)-positive cells) and eosinophils (peroxidase-positive cells) showed similar changes in distribution and abundance in the uterus during the preimplantation period (McMaster et al., 1992a). However, it is difficult to assess the in situ activation of neutrophils and eosinophils in the uterus. Another measure of the uterine responses to inflammatory stimuli is the induction of the metallothionein (MT) genes (De et al., 1990). LPS and several cytokines are potent inducers of MT gene expression in many tissues (Durnam et al., 1984; Bell et al., 1987), including the uterus (De ef al., 1990). In the present study, therefore, the distribution of immune cells was examined by immunohistochemistry, and their activation was assessed by measuring the relative abundance of cytokine mRNAs. Plausible effects of activation of immune cells on uterine gene expression were also determined by delineating the temporal and spatial expression of the MT genes in the mouse uterus specifically at the sites of blastocyst apposition to the luminal epithelium early during the process of implantation.

\section{Materials and Methods}

\section{Animals}

CD-1 outbred mice (Charles River Laboratories, Raleigh, NC) were housed in the animal care facility at the University of Kansas Medical Center according to institutional guidelines for the care and use of laboratory animals. Female mice (48-60days-old) were mated with males of the same strain (day $I=$ vaginal plug). Mating was assumed to have occurred at approximately midnight before the detection of vaginal plugs in the morning. Implantation regions were identified after injection of $0.1 \mathrm{ml}$ Chicago blue- $B$ dye ( $1 \%$ solution into saline: Sigma Chemical Co., St Louis, MO) in to the tail vein 5-10 min before killing. Uteri were collected at intervals of $4 \mathrm{~h}$ beginning at 21:00 h on day 4 and ending at 09:00 h on day 5. Implantation regions were visualized by the presence of blue bands around the uterus. Implantation regions were separated from interimplantation regions by careful dissection and tissues from six mice per group were collected and pooled for RNA extraction or fixed for histology.

\section{LPS and recombinant cytokines}

LPS from Escherichia coli 011:B4 was kindly provided by D. Morrison (University of Kansas Medical Center, Kansas City, KS). Purified recombinant human interleukin-1 $\alpha$ (IL-I $\alpha$, $3 \times 10^{8}$ units $\left.\mathrm{mg}^{-1}\right)$ and recombinant mouse IL-1 $\beta(1 \times$ $10^{8}$ units $\mathrm{mg}^{-1}$ ) were obtained from Hoffmann-LaRoche (Nutley, NJ) and E/I du Pont de Nemours \& Co. (Glenolden, PA), respectively.

\section{Hybridization probes}

Mouse cDNA clones for MT-I (R. D. Palmiter, University of Washington, Seattle, WA) IL-1 $\alpha$ (Hoffmann-LaRoche), IL-1 $\beta$ (E/I du Pont de Nemours \& Co.), IL-6 (DNAX Research Institute of Molecular and Cellular Biology, Inc., Palo Alto, CA), TNF- $\alpha$
(Genentech Inc., San Francisco, CA) and mouse LF (T. Teng, NIEHS, Research Triangle Park, NC) were inserted into the Sp6 or pGEM vectors (Promega Biotech, Madison, WI) and used as templates for the synthesis of $\left[{ }^{32} \mathrm{P}\right]-$ or $\left[{ }^{35} \mathrm{~S}\right]-\mathrm{cRNA}$ probes as described by Melton et al. (1984). These probes had specific activities of about $2 \times 10^{9}$ d.p.m. $\mu \mathrm{g}^{-1}$.

\section{Isolation of total RNA and northern blot hybridization}

Total RNA was extracted from uteri using a modification of the guanidine thiocyanate method of Han et al. (1987) as described by McMaster et al. (1992b). RNA was separated by formaldehyde-agarose gel electrophoresis, and transferred to nitrocellulose membranes and hybridized with $2 \times 10^{7}$ d.p.m. ${ }^{32} \mathrm{P}$-labelled cRNA probe in $0.45 \mathrm{~mol} \mathrm{NaCl} \mathrm{I}^{-1}$ for $24 \mathrm{~h}$ at $68^{\circ} \mathrm{C}$ as described by Andrews et al. (1987). The final post-hybrid washes were $0.3 \times \operatorname{SSC}\left(0.3 \times=0.45 \mathrm{~mol} \mathrm{NaCl}^{-1}\right), 0.1 \%$ SDS at $68^{\circ} \mathrm{C}$. In all experiments, duplicate gels were stained with acridine orange to document the integrity of the RNA samples and to confirm that equal amounts of RNA had been loaded onto each lane. Hybrids were detected by autoradiography at $-80^{\circ} \mathrm{C}$.

\section{In situ hybridization}

The methods for in situ hybridization have been described in detail by Huet-Hudson et al. (1990) and Andrews et al. (1991). Implantation regions were identified by injection of Chicago blue $B$ and carefully separated from non-implantation regions by sharp incisions. Tissue samples were fixed in $4 \%$ paraformaldehyde in phosphate-buffered saline (PBS), dehydrated, cleared, embedded in paraffin wax and sectioned at $7 \mu \mathrm{m}$. Within a given experiment, sections from all experimental samples were mounted onto the same microscope slide, and several slides were prepared. Sections were hybridized with ${ }^{35}$ S-labelled sense or antisense MT-I RNA probes. Autoradiography was for 4 days and slides were counterstained lightly with haematoxylin.

\section{Antibodies and immunohistochemistry}

Interleukin $1 \beta$ was immunolocalized with affinity-purified rabbit anti-mouse IL- $1 \beta$ (E/I du Pont de Nemours \& Co.) at a concentration of $0.5 \mathrm{mg} \mathrm{ml}^{-1}$ (McMaster et al., 1992b). LF antiserum was raised in rabbits against HPLC-purified LF as described by Teng et al. (1986), and was diluted to 1:10000 for immunocytochemistry (McMaster et al., 1992a). Immunolocalization involved a modification of the procedure of $\mathrm{Hsu}$ and Raine (1984) as described by Huet-Hudson et al. (1990) and McMaster et al. (1992a, b). Immunostaining was performed using kits specific to the animal source of the primary antibodies used (Zymed Laboratories, San Francisco, CA). Blocking of endogenous peroxidase was achieved by incubation for $45 \mathrm{~s}$ in $0.23 \%$ periodic acid in PBS after secondary antibody incubation (Kelley et al., 1987). Control sections, incubated with non-immune sera or primary antibodies neutralized with excess of specific antigens, showed no specific staining. Sections were counterstained lightly with haematoxylin, mounted and examined under brightfield. Red deposits (black deposits in photographs) indicated the sites of immunoreactivity. Tissue Downloaded from Bioscientifica.com at 04/26/2023 10:29:34AM 

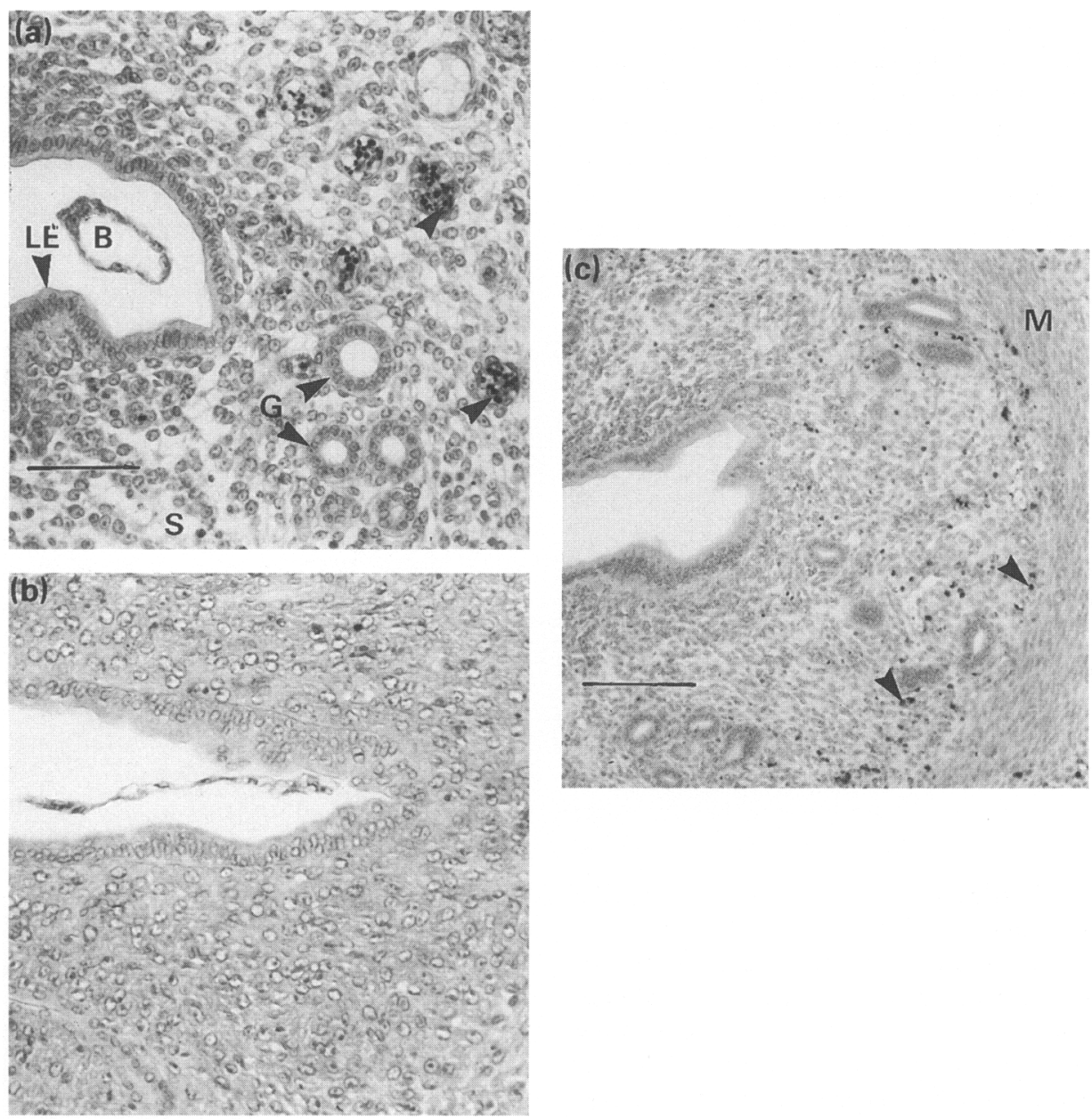

Fig. 1. Immunohistochemical localization of uterine interleukin $1 \beta$ (IL-1 $\beta$ ) during early implantation. Dark deposits (unlabelled arrowheads) indicate immunoreactivity against polyclonal rabbit-anti-mouse IL-1 $\beta$. LE: luminal epithelium; B: blastocyst; G: gland; M: myometrium; S: endometrial stroma. (a) and (b) Implantation sites collected at 21:00 h on day 4 and 09:00 h on day 5, respectively. Bar $=50 \mu \mathrm{m}$. (c) Interimplantation region taken at 01:00 h on day 5 . Bar $=100 \mu \mathrm{m}$.

sections from four implantation sites and four interimplantation regions for each time point were examined on the same slides. Several slides were prepared and examined to determine reproducibility of the results obtained.

\section{Results}

Immunohistochemical localization of IL-1 $\beta$-positive cells (monocytes-macrophages) in the uterus at early stages of implantation

The distribution of IL-1 $\beta$-positive cells was examined by immunohistochemistry in sections from implantation regions containing blastocysts (implantation sites) and in random sections from interimplantation regions (Fig. 1). Immunoneutralization of the primary antibody and reactions with nonimmune sera served as controls for specificity. A few IL-1 $\beta$ positive cells were randomly distributed throughout the deep endometrium and myometrium in both implantation and interimplantation regions throughout the period examined (21:00 h on day 4 to $09: 00 \mathrm{~h}$ on day 5 ). In contrast, IL-1 $\beta$-positive cells were abundant at the sites of implantation within uterine capillary beds, but were rare in interimplantation regions. The presence of these cells in sections of the implantation sites was detected from 21:00 $\mathrm{h}$ on day 4 to $01: 00 \mathrm{~h}$ on day 5, but not thereafter. These results, which were remarkably consistent from animal to animal, suggest that IL- $1 \beta$-positive monocytes are transiently abundant at sites of blastocyst apposition to the luminal epithelium early during the process of implantation.

\section{Uterine cytokine $m R N A$ abundance at early stages of implantation}

Cytokine mRNA abundance during the early phases of implantation was examined in surgically isolated implantation and interimplantation regions of the uterus to assess the functional status of monocytes in the implantation region. Implantation and interimplantation regions were distinguished by the Chicago blue $B$ reaction, and were collected at different times during the evening of day 4 and the morning of day 5. In these mice, the blue reaction was first detected between 20:00 


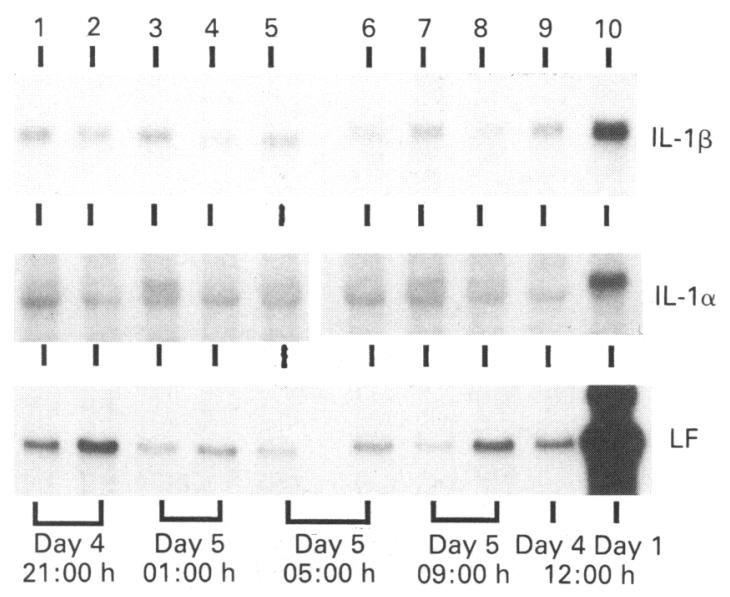

Fig. 2. Northern blot detection of interleukin-1 $\beta$ (IL-1 $\beta$ ), IL-1 $\alpha$ and lactoferrin (LF) mRNAs in implantation and interimplantation regions. Implantation and interimplantation regions were collected from six animals per group at the indicated time and day after ovulation. Total RNA was extracted from implantation (lanes $1,3,5,7$ ) or interimplantation (lanes $2,4,6,8$ ) regions and analysed by northern blot analysis using ${ }^{32} \mathrm{P}$-labelled cRNA probes. Lanes 9 and 10, RNA extracted from the entire uterus on day 4 at 12:00 h and on day 1 at 12:00 h, respectively. Autoradiography was $18 \mathrm{~h}$ for the IL- $1 \beta$ blot, $48 \mathrm{~h}$ for the IL-1 $\alpha$ blot and $3 \mathrm{~h}$ for the LF blot. The transcript sizes for IL-I $\beta$, IL-I $\alpha$ and LF are $1.4,2.2$ and $2.6 \mathrm{~kb}$, respectively.

and 22:00 h on day 4 of pregnancy. Uterine RNA was extracted and analysed by northern blot analysis (Fig. 2). These northern blots also contained RNA from uteri on day 1 of pregnancy (McMaster et al., 1992b) to provide comparative standards for relatively high mRNA abundance and for transcript sizes (Fig. 2, lane 10). Overall, abundance of IL-I $\alpha$ and IL-1 $\beta$ mRNA was low relative to that in the uterus on day 1 . The IL- $1 \alpha$ blot revealed two signals, but the lower band co-migrated with $18 \mathrm{~S}$ ribosomal RNA was detected only after a relatively long autoradiographic exposure time $(48 \mathrm{~h})$, and did not vary in intensity among samples. The upper band co-migrated with the expected IL- $1 \alpha$ transcript. The abundance of IL- $1 \alpha$ and $-\beta$ mRNAs was consistently higher in the implantation regions relative to interimplantation regions at all times examined. This result was reproducible in three separate experiments.

As another control for the northern blot, RNA samples were hybridized to a mouse LF probe. LF mRNA is detected specifically in uterine epithelial cells. This mRNA is abundant on day 1, but thereafter abundance is low (McMaster et al., 1992a). The relative abundance of LF mRNA was higher in interimplantation regions than that in implantation regions (Fig. 2). These results control for integrity of the interimplantation RNA, and suggest that uterine epithelial cell gene expression is differentially regulated early during the process of implantation.

\section{Uterine cytokine $m R N A$ abundance in response to inflammatory stimuli}

Heightened cytokine gene expression (IL-1 $\alpha,-1 \beta,-6$, TNF- $\alpha$ ) is a hallmark of activated macrophages, and treatment with LPS, IL- $I \alpha$ or IL-I $\beta$ causes coordinated rapid, but transient, increases in the relative abundance of each of these cytokine mRNAs in the mouse uterus (De et al., 1990). The effects of treatment with LPS or IL-I $\alpha$ on cytokine gene expression in the uterus was examined on the morning of day 4 of pregnancy (approximately $12 \mathrm{~h}$ before the first visual detection of implantation) (Fig. 3). In control day 4 mice, the abundance of IL-I $\alpha$ and $-\beta$, IL- 6 and TNF- $\alpha$ mRNAs was low in the uterus, but these mRNAs were rapidly induced by LPS (Fig. 3a) or by IL- $1 \alpha$ (Fig. 3b) within 15-60 min of injection. This induction was transient and cytokine mRNA abundance had declined to basal values by $6 \mathrm{~h}$ after treatment. Similar temporal changes in these cytokine mRNAs were noted after injection of IL-1 $\beta$ (data not shown), and previously in several other organs including the uterus (De et al., 1990). As the hybridization probes were of similar length and specific activity, a comparison of the intensities of comparable autoradiographic signals indicates that IL-I $\beta$ mRNA was the most abundant cytokine mRNA detected in all uterine RNA samples examined (Figs 2 and 3). Furthermore, the peak abundance of uterine cytokine mRNAs after LPS or IL-I $\alpha$ was greater than that found in implantation regions (Fig. 2). Overall, the results establish that near the time of implantation, uterine monocytes-macrophages are competent to respond to inflammatory stimuli by activation of cytokine gene expression. These studies, therefore, suggest that the relatively higher abundance of cytokine mRNAs in the implantation regions than in interimplantation regions (Fig. 2) reflects the number of monocytes (Fig. 1) rather than acute high level activation of these types of cell in response to the implanting blastocyst.

Immunohistochemical localization of LF-positive cells in the uterus during the early events of implantation

Although LF is a secretory product of uterine epithelial cells that contain significant amounts of LF mRNA, this protein is also an established marker for mature neutrophils. LF-positive cells in the uterine stroma were identified by immunohistochemistry during the early process of implantation (Fig. 4). In the implantation sites on the morning of day 5, subepithelial LF-positive neutrophils were prominent at 01:00 h and 05:00 h, but were sparse at 09:00 h. About 12-24 LF-positive neutrophils per section were detected in the antimesometrial stroma, basolateral to the basement membrane of the luminal epithelium apposed to the trophectoderm epithelium (Fig. 4). In contrast, in the interimplantation region, these cells were widely dispersed in the deep stroma and myometrium. These data establish that the temporal and spatial distribution of LF-positive neutrophils in the stroma are tightly regulated at the site of blastocyst implantation during the early phases of this process.

\section{Uterine MT $m R N A$ abundance during early implantation}

Although the in situ activation of inflammatory cells at implantation sites could not be assessed directly, one measure of the uterine responses to inflammatory stimuli is the induction of MT genes (De et al., 1990). MT mRNA was localized by in situ hybridization in implantation sites and interimplantation regions between $21: 00 \mathrm{~h}$ on day 4 and 09:00 h on day 5 (Fig. 5). Only results for the implantation sites are shown. A unique temporal and cell-specific expression of the MT gene was noted Downloaded from Bioscientifica.com at 04/26/2023 10:29:34AM 
PROBE (a)

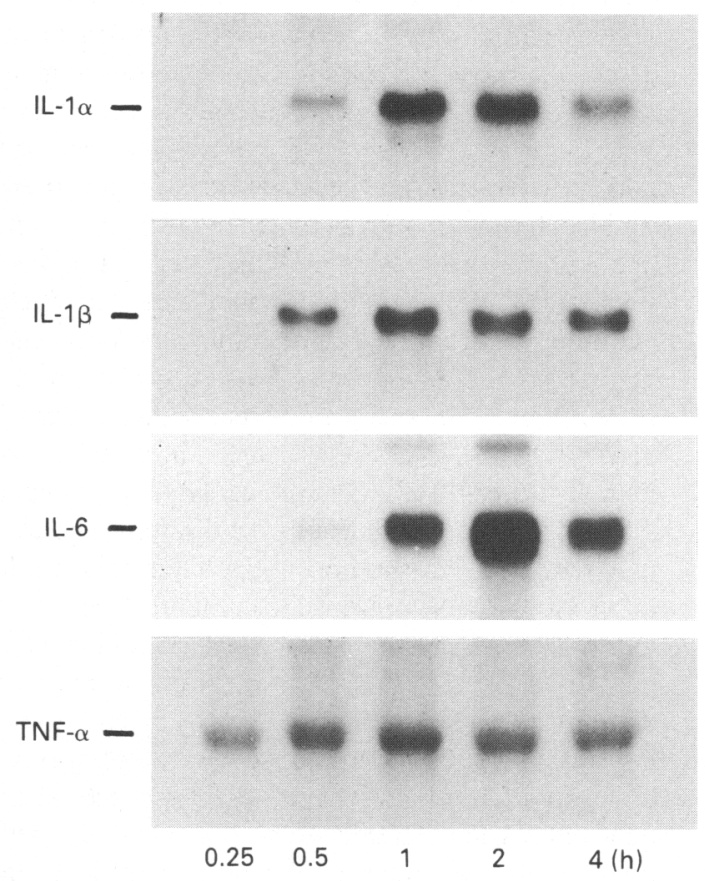

PROBE (b)

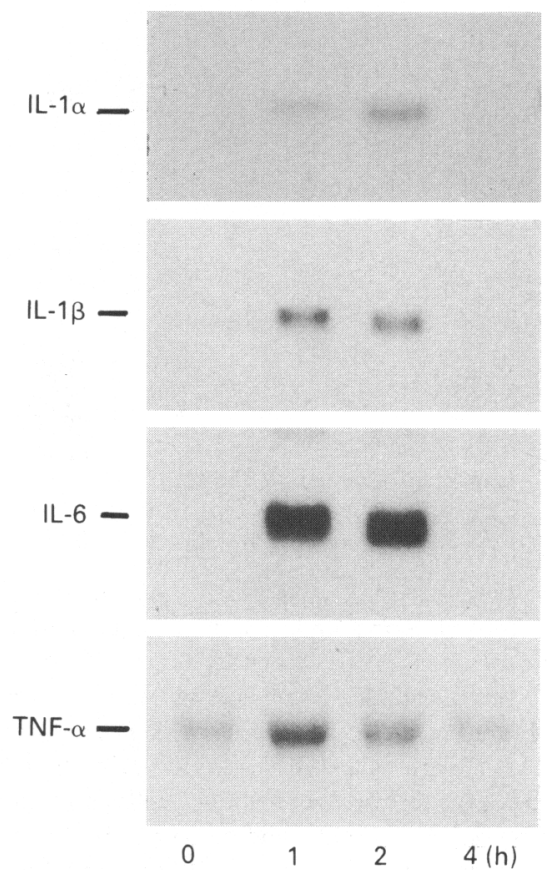

Fig. 3. Acute effects of lipopolysaccharide (LPS) and interleukin $1 \alpha$ (IL- $1 \alpha$ ) on uterine cytokine mRNA abundance on day 4 of pregnancy. Female CD-1 mice (three per group) were injected i.p. with; (a), $100 \mu \mathrm{g}$ LPS and (b), $1 \mu \mathrm{g}$ recombinant human IL- $1 \alpha\left(3 \times 10^{5}\right.$ units $)$. Uterine RNA was isolated at the indicated times after injection $(15 \mathrm{~min}-4 \mathrm{~h})$, and replicate gels were analysed by northem blot hybridization using cRNA probes specific for mouse IL-1 $\alpha$, IL-1 $\beta$, IL- 6 or tumour necrosis factor $\alpha$ (TNF- $\alpha$ ). Hybrids were detected by autoradiography, but the exposure times for each probe differed, and only relevant portions of the blots are shown. IL-1 $\beta$ hybrids were detected after $8 \mathrm{~h}$ exposure, IL-I $\alpha$ after $18 \mathrm{~h}$, and IL- 6 and TNF- $\alpha$ after $36 \mathrm{~h}$. The transcript sizes for IL- 6 and TNF- $\alpha$ are 1.2 and $1.8 \mathrm{~kb}$, respectively.

during this period. Early in the implantation process (Fig. 5, 21:00 $\mathrm{h}$ on day 4), no specific hybridization signal above background values was detected in implantation sites, whereas at 05:00 h on day $5 \mathrm{MT}$ mRNA accumulation apparently increased in the antimesometrial region, and by $09: 00 \mathrm{~h}$ on day 5 , clear hybridization signals were detected specifically in antimesometrial epithelial cells surrounding the implanting blastocyst and in deeper stromal cells around the implantation chamber (Fig. 5, 09:00 on day 5). However, MT mRNA was not detected in subepithelial stromal cells located immediately under the implanting blastocyst (Fig. 5, 09:00 h on day 5). These cells are the first to show morphological signs of decidualization. Control experiments involving sense-strand hybridization to sections from implantation sites and antisense hybridization to sections from interimplantation regions showed no signals above background.

\section{Discussion}

Similarities between implantation and inflammation have long been recognized (reviewed in Finn, 1986), and a role for immune cells in the process of implantation has been suggested (Noun and Acker, 1989; King and Loke, 1990; Tachi, 1991). It was further suggested that uterine macrophages play a key role in implantation in rodents (Tachi, 1991). However, definitive evidence for such functions is difficult to obtain. In mice, the transient abundance of IL-I $\beta$-positive monocytes and the unique distribution of LF-positive neutrophils during early implantation support the concept that these types of cell are involved in implantation, and may participate during very early phases of this process.

An abundance of IL- $1 \beta$-positive monocytes located in stromal capillaries at blastocyst implantation sites has not been reported previously, but Tachi (1991) suggested that there was a pool of such cells in the implantation region. However, cells exhibiting phagocytotic activity, nonspecific esterase activity (reviewed in Tachi, 1991) or cell surface antigens (De et al., 1991), characteristics of cells of the macrophage lineage, have been detected in the stroma of the implantation region, and in implantation sites (Tachi, 1991). Thus, the IL-1 $\beta$-positive cells, detected in the present study, may also represent a subpopulation of the monocytes-macrophages present in the implantation region. Although IL-1 $\beta$ may be synthesized by other types of cell, a major source of this cytokine is the monocytemacrophage. IL-1 $\beta$ mRNA is abundant in these cells and represents $1-2 \%$ of the total mRNA in LPS-activated macrophages (Dinarello, 1987). Immunohistochemical detection of IL-1 $\beta$ also strongly suggests that monocytes-macrophages are the major, if not sole, source of this cytokine in the uterus.

The ability of LPS to increase cytokine gene expression in the uterus rapidly, and the relatively low abundance of cytokine 

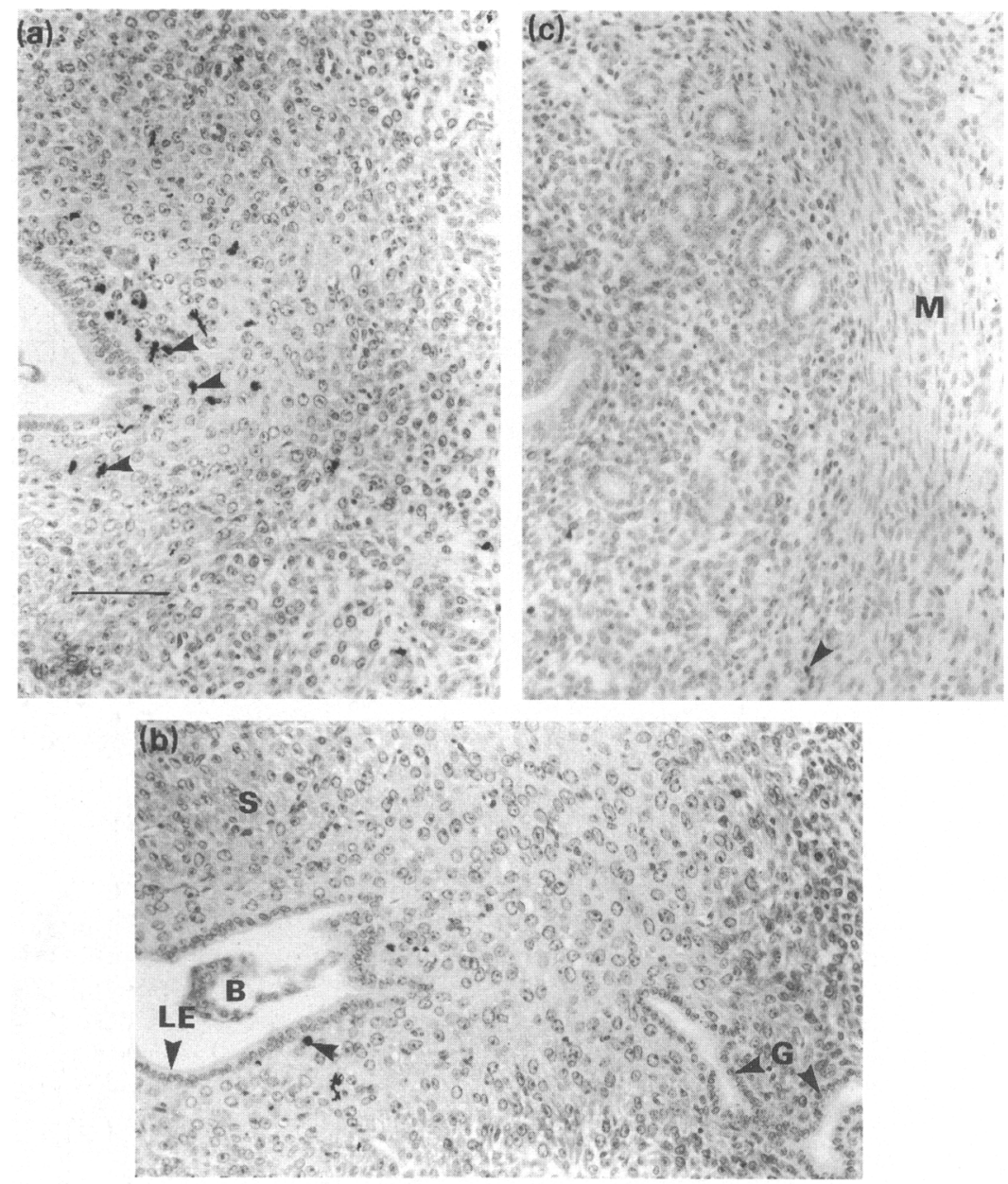

Fig. 4. Immunohistochemical localization of lactoferrin (LF) during early implantation. Dark deposits indicate immunoreactivity (unlabelled arrowheads) against polyclonal rabbit anti-mouse LF. LE: luminal epithelium; B: blastocyst; G: gland; M: myometrium; $\mathrm{S}$ : endometrial stroma. (a) and (b) The antimesometrial area of implantation sites collected at $05: 00 \mathrm{~h}$ and 09:00 h on day 5, respectively. (c) The antimesometrial area of an interimplantation region collected at $01: 00 \mathrm{~h}$ on day 5 . Bar $=50 \mu \mathrm{m}$.

mRNAs in the implantation region suggest that monocytesmacrophages in the implantation region are not functionally highly activated during early implantation, but are competent to respond to an inflammatory stimulus. In this regard, the murine decidual cell substratum may inhibit several macrophage functions, including adhesion, spreading and tumour cell killing (Redline et al., 1990), and the absence of these cells in the rodent deciduum during the post-implantation period has been reported (Noun et al., 1989; see Tachi, 1991). Effects of decidual cells on macrophage cytokine gene expression have not been studied.

As reported here, LF-positive neutrophils are concentrated amongst the earliest decidualizing cells that underlie the implanting blastocyst. During the course of our study, Finn and Pope (1991) independently observed that neutrophils become concentrated at implantation sites at $100 \mathrm{~h}$ after mating. In our studies, 05:00 h on day 5 is approximately $101 \mathrm{~h}$ after mating. Thus, these results are in good agreement. In contrast, another recent study reported a lack of neutrophils at implantation sites in rats (Rogers et al., 1992), indicating species differences in this response.
Several mediators produced by neutrophils in response to cytokines and other activating signals could play important roles in implantation. These include matrix metalloproteinases that degrade laminin and collagen (Heck et al., 1990), and reactive oxygen species and lysosomal contents that are potentially capable of mediating epithelial degeneration (Halliwell and Gutteridge, 1990; Kapp and Zeck-Kapp, 1990). Degradation of the epithelial cell basement membrane, degeneration of epithelial cells at sites of implantation and extensive tissue remodelling are critical for successful implantation and decidualization.

Of interest here was the observation that the MT gene(s) was activated specifically in luminal epithelial cells juxtaposed to the implanting blastocyst and in the deeper stroma. The activation of this gene(s) occurred soon after the transient neutrophil infiltration into the subepithelial region and the accumulation of monocytes in the stromal compartment. Since MT can be induced by oxidative stress (Baumann et al., 1991), it is possible that the production of reactive oxygen species by neutrophils accounts for the induction of epithelial MT gene expression. Other workers have also suggested roles for the superoxide 

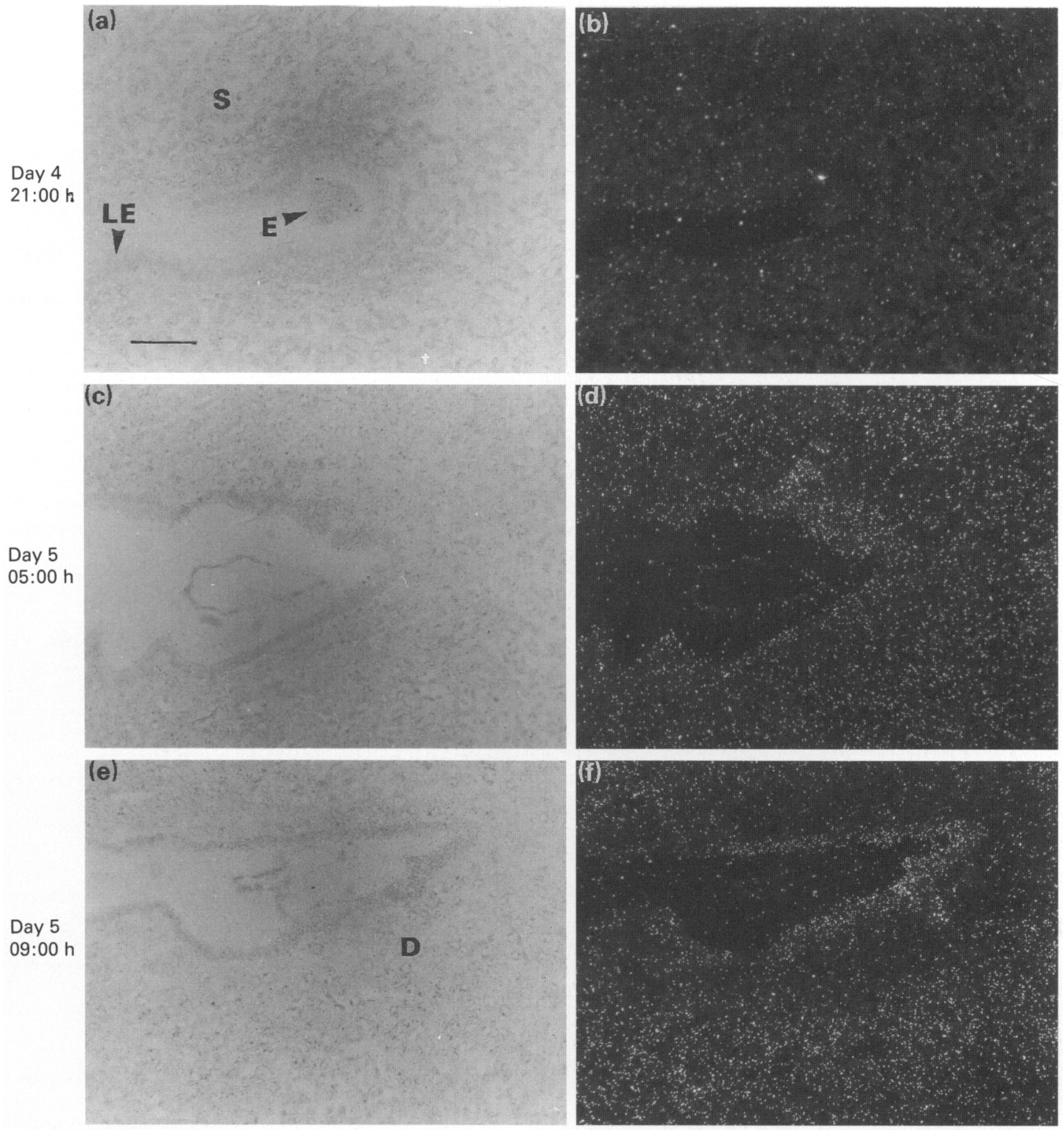

Fig. 5. In situ hybridization detection of metallothionein (MT) mRNA at implantation sites. Paraformaldehyde-fixed paraffin sections were processed for in situ hybridization. (a), (c) and (e) Brightfield and (b), (d) and (f) darkfield photomicrographs of uterine sections containing blastocysts that were collected at the indicated time and day of pregnancy, and hybridized with a ${ }^{35}$ S-labelled mouse MT cRNA probe. Autoradiographic grains appear as white dots in the darkfield photomicrographs. LE: luminal epithelium; E: embryo; S: endometrial stroma; D: decidualizing stroma. Bar $=50 \mu \mathrm{m}$.

anion radical in the process of implantation in mice (Laloraya et al., 1989; Laloraya, 1990), and higher concentrations of this oxygen radical have been detected in the uterus on day 5 of pregnancy (Laloraya et al., 1989). However, free radicals may also be involved in LPS-induced fetal resorption in mice (Gower et al., 1990). Although oxidative stress can induce MT, a wide range of inflammatory cytokines can also induce these genes (Andrews, 1990). Thus, epithelial and stromal MT gene expression reflects a localized and highly controlled inflammatory response.

The mechanisms responsible for the recruitment, migration and activation of neutrophils and other immune cells at implantation sites are unknown. The transient accumulation of IL-1 $\beta$ positive monocytes in the stromal capillaries suggests that there are specific cell adhesion molecules on the endothelium (see Kishimoto, 1991). The relative paucity of macrophages in the implantation region suggests an inhibition of migration of the IL-1 $\beta$-positive monocytes out of the capillary bed. Alternatively, macrophages may be present in the stroma but devoid of cytokines, thus rendering them undetectable by immunohistochemistry, or perhaps these cells migrate out of the implantation region rapidly. The local production of monocyte TNF- $\alpha$ and IL-I could enhance neutrophil chemotaxis and adhesion to the vascular endothelium (Sayers et al., 1988; Mason and Van Epps, 1989; Schlayer et al., 1989). Furthermore, these cytokines can affect production of the neutrophil chemotactic factors by endothelial cells, fibroblasts and monocytes Downloaded from Bioscientifica.com at 04/26/2023 10:29:34AM 
(Matsushima et al., 1988; Strieter et al., 1989a, b). Thus, cytokine production at sites of implantation may recruit neutrophils into the area, but is unlikely to explain the selective localization of these cells near the epithelium underlying the implanting blastocyst. Whether a neutrophil chemotactic signal originates from the blastocyst or the epithelium remains to be determined. However, TGF- $\beta 1$, which is produced in the peri-implantation mouse uterus (Tamada et al., 1990) as well as by the mouse blastocyst (Rappolee et al., 1988; Paria et al., 1992), has been shown to be the most potent neutrophil chemotactic factor yet identified in humans (Reibman et al., 1991).

Two instances of apparent differences in gene expression in epithelial cells from specific regions of the uterus were noted by northern blot analysis of mRNA. The first instance involved LF mRNA which was higher in interimplantation regions relative to implantation regions. This mRNA is restricted to uterine epithelial cells (Pentacost and Teng, 1987; McMaster et al., 1992a). The second instance involved MT mRNA, which was increased specifically in antimesometrial luminal epithelial cells underlying the implanting blastocyst. These results suggest differential regulation of gene expression between implantation and interimplantation regions, but the mechanism of this regulation is not clear.

This work was supported, in part, by grants from the NIEHS (ES04725 to G. K. Andrews), NICHD (HD-12304 to S. K. Dey) and a Predoctoral Graduate Research Training Fellowship from the March of Dimes Birth Defects Foundation (no. 18-87-05 to M. T. McMaster). Thanks are due to $C$. O'Rourke and C. Gore for expert technical assistance, to $R$. Newton for recombinant mouse IL-I $\beta$ and rabbit antimouse IL-1 $\beta$ and to T. Teng for providing the rabbit anti-mouse LF and the mouse LF $c D N A$.

\section{References}

Andrews GK (1990) Regulation of metallothionein gene expression Progress in Food Nutrition Science 14 193-258

Andrews GK, Lehman LD, Huet YM and Dey SK (1987) Metaliothionein gene regulation in the preimplantation rabbit blastocyst Development 100 463-465

Andrews GK, Huet-Hudson YM, Paria B, McMaster MT, De SK and Dey SK (1991) Metallothionein gene expression and metal regulation during preimplantation mouse embryo development Developmental Biology $\mathbf{1 4 5}$ 13-27

Baumann JW, Liu J, Liu YP and Klaassen CD (1991) Increase in metallothionein produced by chemicals that induce oxidative stress Toxicology and Applied Pharmacology $110347-354$

Beer AE and Billingham RE (1978) Immunoregulatory aspects of pregnancy Federation Proceedings 37 2374-2378

Bell JU, Lawman MJ, Lopez JM, DesJardin LE and Applewhite LA (1987) Effects of type I interferon-inducing agents on hepatic metallothionein Experientia Supplement 52 581-586

De M, Choudhuri R and Wood GW (1991) Determination of the number and distribution of macrophages, lymphocytes, and granulocytes in the mouse uterus from mating through implantation Journal of Leukocyte Biology 50 252-262

De SK, McMaster MT and Andrews GK (1990) Endotoxin induction of murine metallothionein gene expression Journal of Biological Chemistry 265 15267-15274

Dinarello CA (1987) The biology of interleukin 1 and comparison to tumor necrosis factor Immunology Letters 16 227-232

Durnam DM, Hoffman JS, Quaife CJ, Benditt EP, Chen H, Brinster RL and Palmiter RD (1984) Induction of mouse metallothionein-I mRNA by bacterial endotoxin is independent of metals and glucocorticoids Proceedings of the National Academy of Sciences USA 81 1053-1056
Finn CA (1986) Implantation, menstruation and inflammation Biological Reviews $61313-328$

Finn CA and Pope MD (1991) Infiltration of neutrophil polymorphonuclear leukocytes into the endometrial stroma at the time of implantation of ova and the initiation of the oil decidual cell reaction in mice Journal of Reproduction and Fertility 91 365-369

Gower JD, Baldock RJ, O'Sullivan AM, Dore CJ, Coid CR and Green CJ (1990) Protection against endotoxin-induced foetal resorption in mice by desferrioxamine and ebselen International Journal of Experimental Pathology $\mathbf{7 1}$ 433-440

Halliwell B and Gutteridge JMC (1990) Free radicals and metal ions in human disease Methods in Enzymology 186 1-85

Han JH, Stratowa C and Rutter WJ (1987) Isolation of full-length putative rat lysophospholipase cDNA using improved methods for mRNA isolation and cDNA cloning Biochemistry 26 1617-1625

Heck LW, Blackburn WD, Irwin MH and Abrahamson DR (1990) Degradation of basement membrane laminin by human neutrophil elastase and cathepsin $\mathrm{G}$. American Joumal of Pathology 136 1267-1274

Hsu SM and Raine L (1984) The use of avidin-biotin-peroxidase complex (ABC) in diagnostic and research pathology. In Advances in Immunocytochemistry, pp 31-42. Ed. RA DeLellis Mason Publishing, New York

Huet-Hudson YM, Chakraborty C, De SK, Suzuki Y, Andrews GK and Dey SK (1990) Estrogen regulates the synthesis of epidermal growth factor in mouse uterine epithelial cells Molecular Endocrinology 4 510-52.3

Kapp A and Zeck-Kapp G (1990) Activation of the oxidative metabolism in human polymorphonuclear neutrophilic granulocytes: the role of immuno-modulating cytokines. Journal of Investigative Dermatology 95, 94S-99S

Kelley J, Whelan CA, Weir DG and Reighery C (1987) Removal of endogenous peroxidase from cryostat section for immunoperoxidase visualization of monoclonal antibodies Journal of Immunology Methods 96 127-132

Kennedy TG (1977) Evidence for a role of prostaglandins in the initiation of blastocyst implantation in the rat Biology of Reproduction 16 286-291

King A and Loke YW (1990) Uterine large granular lymphocytes: a possible role in embryonic implantation? American Journal of Obstetrics and Gynecology 162 308-310

Kishimoto TK (1991) A dynamic model for neutrophil localization to inflammatory sites Journal of NIH Research 3 75-77

Laloraya M (1990) Fluidity of the phospholipid bilayer of the endometrium at the time of implantation of the blastocyst - a spin label study Biochemical and Biophysical Research Communications $167561-567$

Laloraya M, Kumar PG and Laloraya MM (1989) A possible role of superoxide anion radical in the process of blastocyst implantation in Mus musculus. Biochemical and Biophysical Research Communications 161 762-769

McMaster MT, Teng CT, Dey SK and Andrews GK (1992a) Lactoferrin in the mouse uterus: analyses of the preimplantation period and regulation by ovarian steroids Molecular Endocrinology 6 10I-111

McMaster MT, Newton RC, Dey SK and Andrews GK (1992b) Activation and distribution of inflammatory cells in the mouse uterus during the preimplantation period Joumal of Immunology 148 1699-1705

Mason MJ and Van Epps DE (1989) In vivo neutrophil emigration in response to interleukin-I and tumor necrosis factor-alpha Journal of Leukocyte Biology $\mathbf{4 5}$ 62-68

Matsushima K, Morishita K, Yoshimura T, Lavu S, Kobayashi Y, Lew W, Appella E, Kung HF, Leonard EJ and Oppenheim JJ (1988) Molecular cloning of a human monocyte-derived neutrophil chemotactic factor (MDNCF) and the induction of MDNCF mRNA by interleukin 1 and tumor necrosis factor Joumal of Experimental Medicine 167 1883-1893

Melton DA, Krieg PA, Rebegliati MR, Maniatis T, Kinn K and Green MR (1984) Efficient in vitro synthesis of biologically active RNA and RNA hybridization probes from plasmids containing a bacteriophage SP6 promoter Nucleic Acids Research 12 7035-7057

Noun A and Acker GM (1989) Cells bearing granulocyte-macrophage and T lymphocyte antigens in the rat uterus before and during ovum implantation Clinical Immunology 78 494-498

Paria BC, Jones KL, Flanders KC and Dey SK (1992) Localization and binding of transforming growth factor- $\beta$ isoforms in preimplantation mouse embryos and in delayed and activated blastocysts Developmental Biology 151 91-104

Pentacost BT and Teng CT (1987) Lactotransferrin is the major estrogen inducible protein of mouse uterine secretions Joumal of Biological Chemistry 262 10134-10139

Potts DM (1968) The ultrastructure of implantation in the mouse Joumal of Anatomy 103 77-90 
Psychoyos A (1973) Endocrine control of egg implantation. In Handbook of Physiology. pp 187-215 Eds RO Greep, EG Astwood and SR Geiger. American Physiological Society, Washington DC

Rappolee DA, Brenner CA, Schultz R, Mark D and Werb Z (1988) Developmental expression of PDGF, TGF- $\alpha$ and TGF- $\beta$ genes in preimplantation mouse embryos Science 242 1823-1825

Redline RW, McKay DB, Vazquez MA, Papaioannou VE and Lu CY (1990) Macrophage functions are regulated by the substratum of murine decidual stromal cells Journal of Clinical Investigation 80 1951-1958

Reibman J, Meixler S, Lee TC, Gold LI, Cronstein BN, Haines KA, Kolasinksi SL and Weissmann G (1991) Transforming growth factor $\beta 1$, a potent chemoattractant for human neutrophils, bypasses classic signal-transduction pathways Proceedings of the National Academy of Sciences USA 88 6805-6809

Rogers PAW, Macpherson AM and Beaton L (1992) Reduction in endometrial neutrophils in proximity to implanting rat blastocysts Joumal of Reproduction and Fertility 96 283-288

Sayers TJ, Wiltrout TA, Bull CA, Denn AC, Pilaro AM and Lokesh B (1988) Effects of cytokines on polymorphonuclear neutrophil infiltration in the mouse: prostaglandin- and leukotriene-independent induction of infiltration by IL-1 and tumor necrosis factor Joumal of Immunology 141 1670-1677

Schlayer HJ, Laaff H, Peters T, Woort-Menker M, Estler HC, Karck U, Schaefer HE and Decker K (1989) Involvement of tumor necrosis factor in endotoxin- triggered neutrophil adherence to sinusoidal endothelial cells of mouse liver and its modulation in acute phase Journal of Hepatology 7 239-249

Strieter RM, Kunkel SL, Showell HJ, Remick DG, Phan SH, Ward PA and Marks RM (1989a) Endothelial cell gene expression of a neutrophil chemotactic factor by TNF- $\alpha$, LPS, and IL-1 $\beta$ Science 243 1467-1469

Strieter RM, Phan SH, Showell HJ, Remick DG, Lynch JP, Genord M, Raiford C, Eskandari M, Marks RM and Kunkel SL (1989b) Monokine-induced neutrophil chemotactic factor gene expression in human fibroblasts Journal of Biological Chemistry $26410621-10626$

Tachi C (1991) Uterine macrophages and their function in implantation of Muridae rodents. In Uterine and Embryonic Factors in Early Pregnancy, PP 119-138 Eds JF Strass III and CR Lyttle. Plenum Press, New York

Tachi C, Tachi S, Knyszynski A and Linder HR (1981) Possible involvement of macrophages in embryo-maternal relationships during embryo implantation in the rat Journal of Experimental Zoology $21781-92$

Tamada H, McMaster MT, Flanders KC, Andrews GK and Dey SK (1990) Cell type-specific expression of TGF- $\beta_{1}$ in the mouse uterus during the periimplantation period Molecular Endocrinology 4 965-972

Teng CT, Walker MP, Bhattacharyya SN, Klapper DG, DiAugustine RP and McLachlan JA (1986) Purification and properties of an oestrogen-stimulated mouse uterine glycoprotein (approx. $70 \mathrm{kDa}$ ) Biochemical Journal $\mathbf{2 4 0}$ 413-422 